\title{
Hydrogeologic Aspects of the Knippa Gap Area in Eastern Uvalde and Western Medina Counties, Texas
}

\section{The Knippa Gap}

The Edwards aquifer is the primary source of water for a large area of south-central Texas (fig. 1). The geologic structure, stratigraphy, and hydrogeologic characteristics of rocks that make up the Edwards aquifer and its confining units control the amount and direction of groundwater flowing through the aquifer. Groundwater flow pathways in the western part of the Edwards aquifer are complex, and this complexity is associated with the Balcones Fault Zone, a prominent structural feature in south-central Texas, and other related geologic structures. The existence of a geologic structure known as the "Knippa Gap" first was postulated by Maclay and Land (1988) as a subsurface structural low or "gap" located in an area beneath Knippa and Sabinal, Tex. (fig. 1), that restricts regional groundwater movement from the west to the east. The existence of the gap was postulated on the

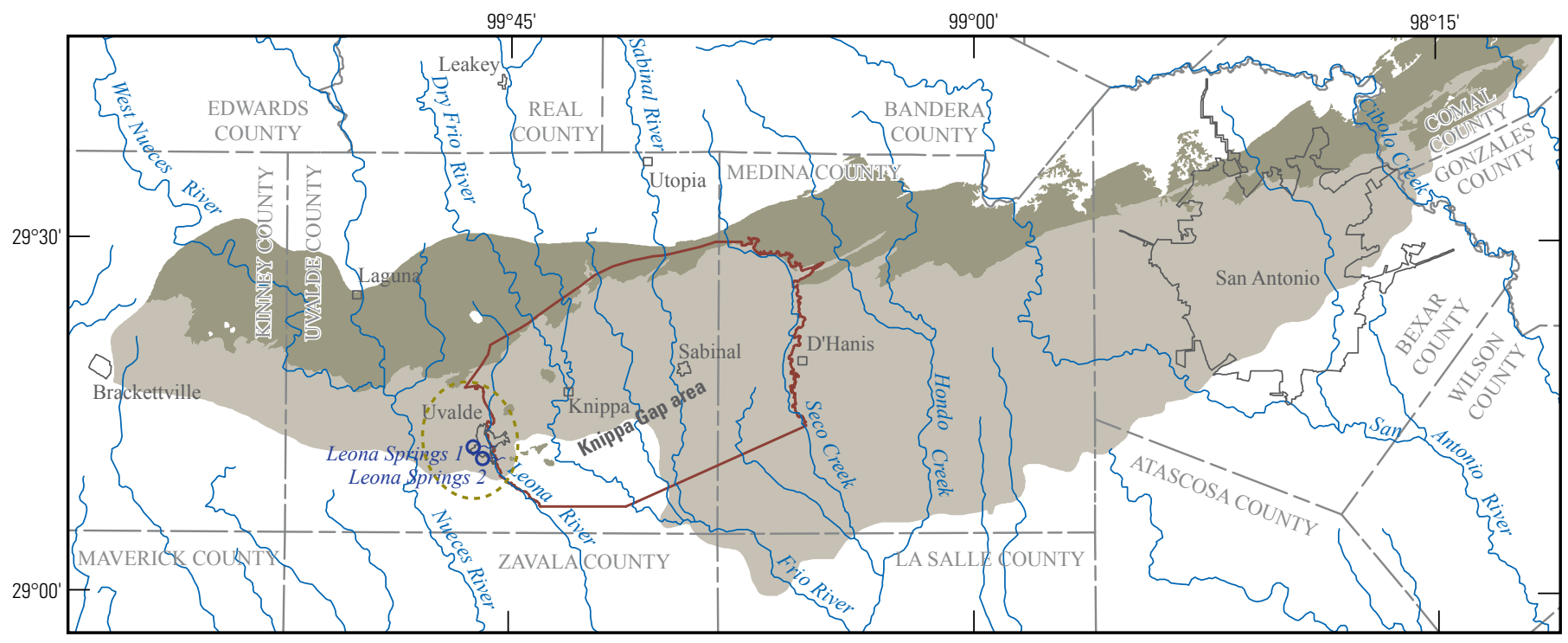

Base modified from U.S. Geological Survey 1:250,000-scale digital data Universal Transverse Mercator projection, zone 14 North American Datum of 1983

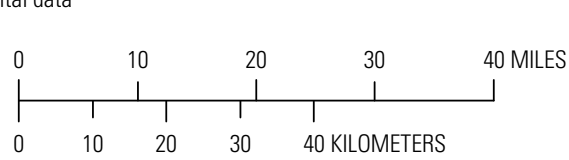

EXPLANATION

Edwards aquifer (George and others, 2011) Outcrop

- Study boundary

- - Approximate location of the Uvalde Salient Leona Springs

Spring and name$$
\text { (1) }
$$

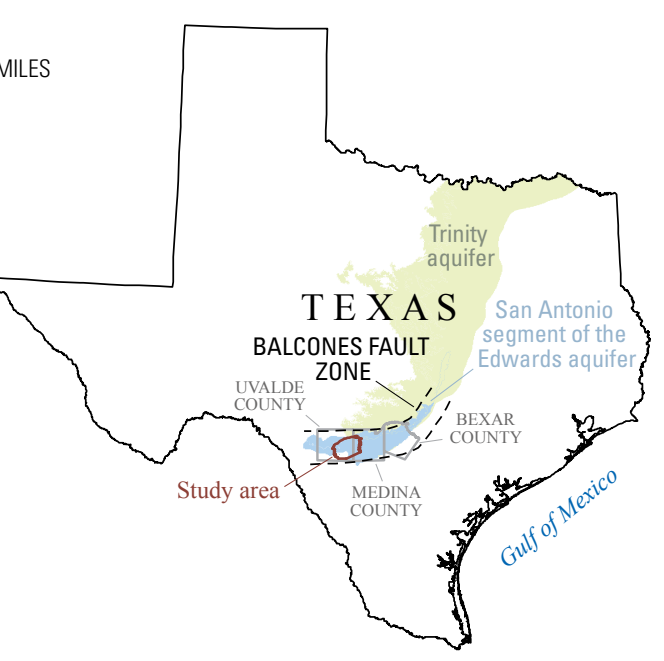

Figure 1. Location of the Knippa Gap area in south-central Texas. 




basis of a series of numerical simulations of groundwater flow made by Maclay and Land (1988) in an attempt to synthesize the geologic, structural, and hydrogeologic characteristics of the aquifer.

Although the presence of the Knippa Gap near the boundary of the Devils River Trend and Maverick Basin depositional provinces (fig. 2) in eastern Uvalde and western Medina Counties, Tex., had been supported by
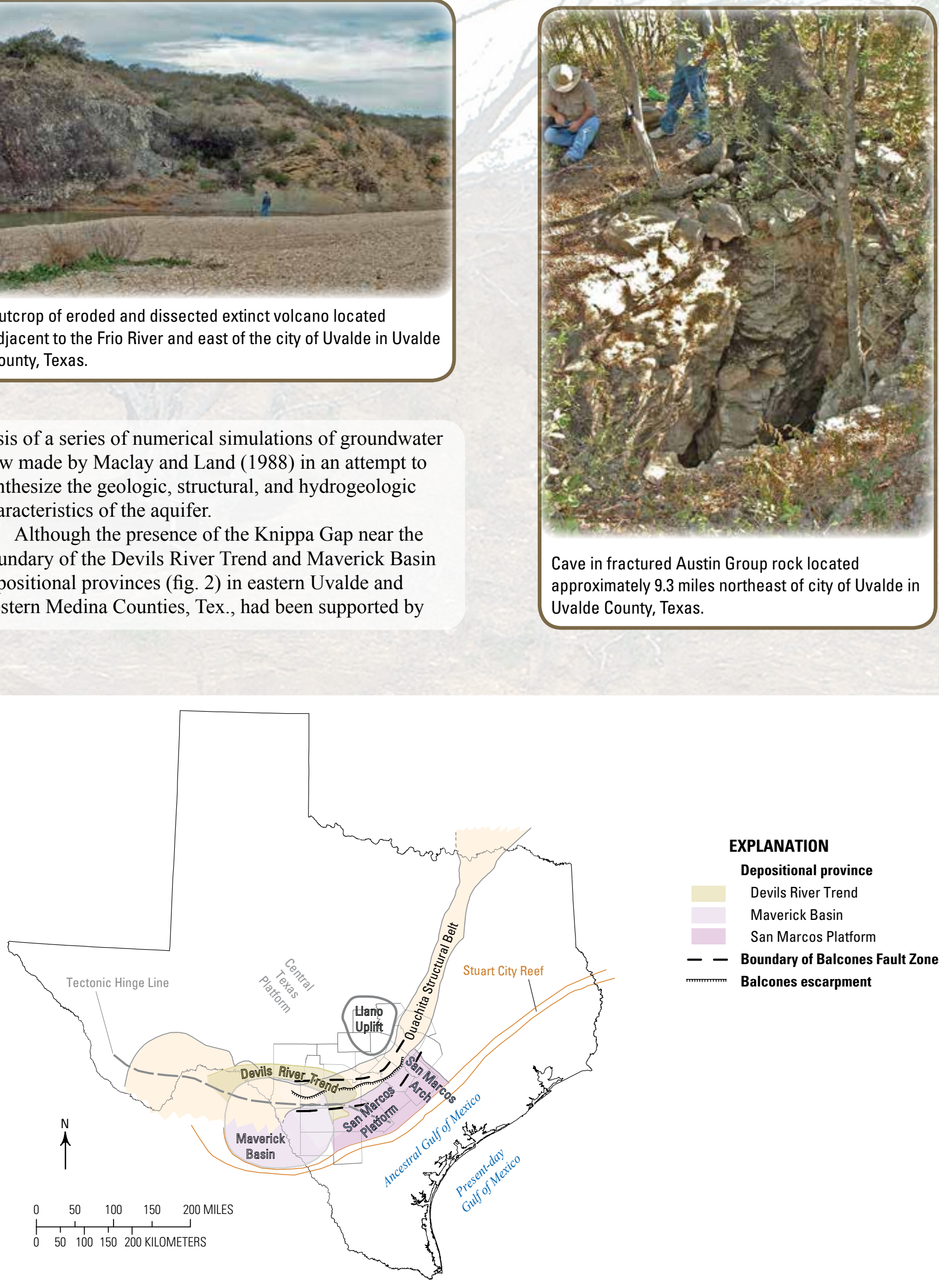

Figure 2. Regional depositional provinces, boundary of the Balcones Fault Zone, and the Balcones escarpment in south-central Texas. 
numerical simulations, efforts to map it in detail had not been previously attempted. In cooperation with the U.S. Army Corps of Engineers, the U.S. Geological Survey developed the first detailed surficial geologic map of the Knippa Gap area with data and information obtained from previous investigations and field observations (Clark and others, 2013, plate 1). A simplified version of the detailed geologic map depicting the hydrologic units, faulting, and structural dips of the Knippa Gap area is provided in figure 3.

Surficial geologic units and surficial expression of fractures, faults, and lineaments were identified and mapped with the aid of well log data, aerial imagery, rock and soil exposures, and observed changes in vegetation and drainage patterns. In eastern Uvalde and western Medina Counties, sedimentary rocks from the Lower Cretaceous to the Pleistocene along with igneous rocks from the Upper Cretaceous are exposed at land surface and in roadside outcrops (Clark and others, 2013). These rocks include limestone, chalk, gravel, sand, silt, shale, clay, and basalt. Igneous rocks also were mapped to show the spatial distribution of the igneous bodies and their relation to the geologic structure of the area. Borehole geophysical data were used to determine formational contacts in the subsurface and regional dips in each of the geologic units. This information was used to interpret structural dip directions and the approximate location of the structural trough in the Knippa Gap (fig. 4).

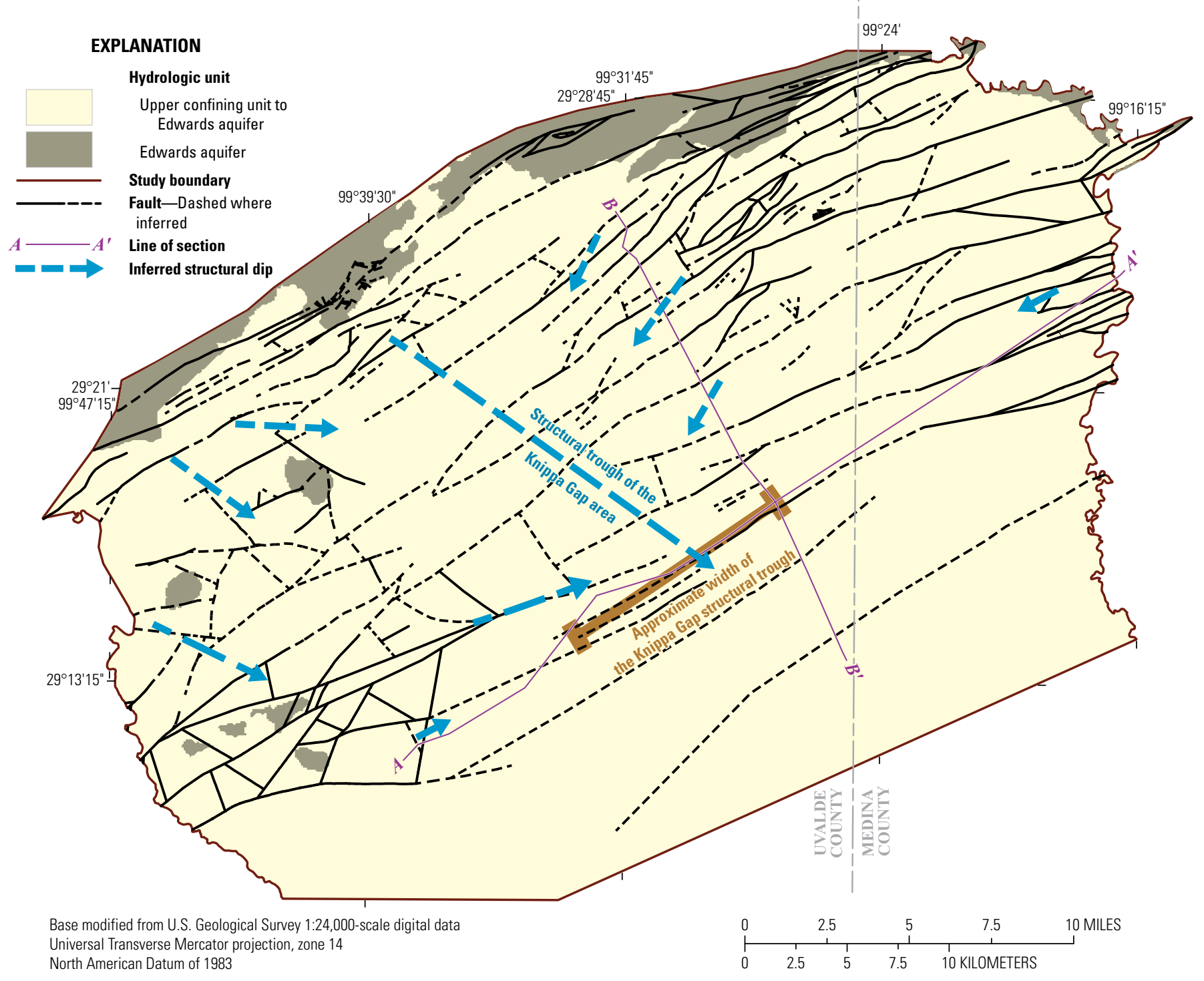

Figure 3. Hydrologic units, faulting, and structural dips of the Knippa Gap area in south-central Texas. Full version of geologic plate is available in Clark and others (2013). 


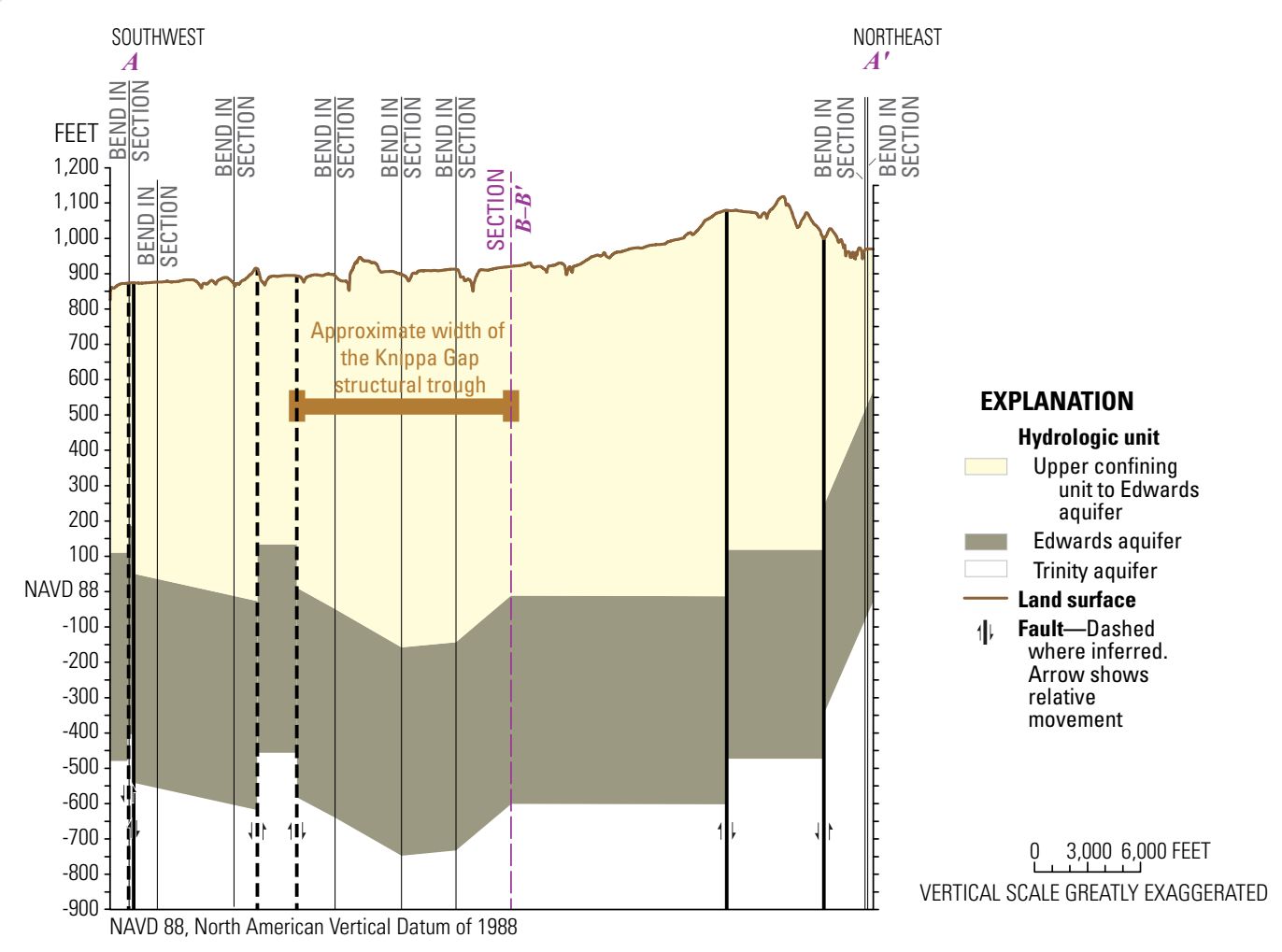

Figure 4. Hydrologic section $A-A^{\prime}$ showing approximate width of the structural trough in the Knippa Gap area. Location of trace $A-A^{\prime}$ shown on figure 3.

\section{Sources of Groundwater in the Knippa Gap Area}

The Edwards aquifer, a karst aquifer with large porosity and permeability that includes geologic units from the Devils River Trend and the Maverick Basin depositional provinces, is the primary source of water in the Knippa Gap area (fig. 3). The Edwards aquifer in the Devils River Trend is one of the most porous and permeable units in the area, with permeable zones that generally are associated with solutionally enlarged bedding planes and fractures. Although most of the permeability probably results from fractures, the aquifer also contains bedding plane, fracture, breccia, vug, channel, and cave porosity. The vertical fractures near the top of the Edwards aquifer in the Devils River Formation provide the most effective paths for recharge, and where subaerially exposed, these fractures greatly increase the rate of recharge when precipitation occurs in the area (fig. 3).






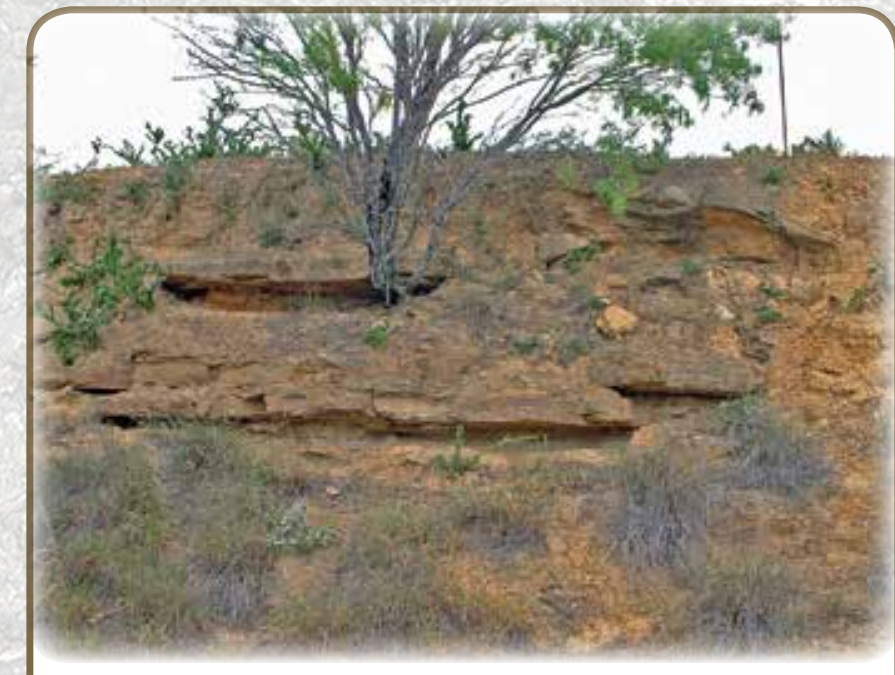

Sandstone ledges in the Escondido Formation located approximately 7 miles south-southeast of the community of D'Hanis in Medina County, Texas.

Additional minor sources of water in the Knippa Gap area include the Leona aquifer, a minor aquifer associated with alluvium of the Pleistocene Leona Formation that crops out along stream channels; the Uvalde Gravel; the Indio Formation; the igneous basalts and serpentines; and other Edwards aquifer confining units (Del Rio Clay, Buda Limestone, Eagle Ford Group, Austin Group, Anacacho Limestone, and Escondido Formation) (Clark and others, 2013).

\section{Complex Structure and Groundwater Flow Paths}

The Balcones Fault Zone is a structurally complicated, Miocene-aged fault complex that trends approximately west to east across Uvalde and Medina Counties and is composed of high-angle, en echelon, vertical or nearly vertical normal faults that are downthrown to the southeast (fig. 5). The Balcones Fault Zone contains relay ramps that commonly form

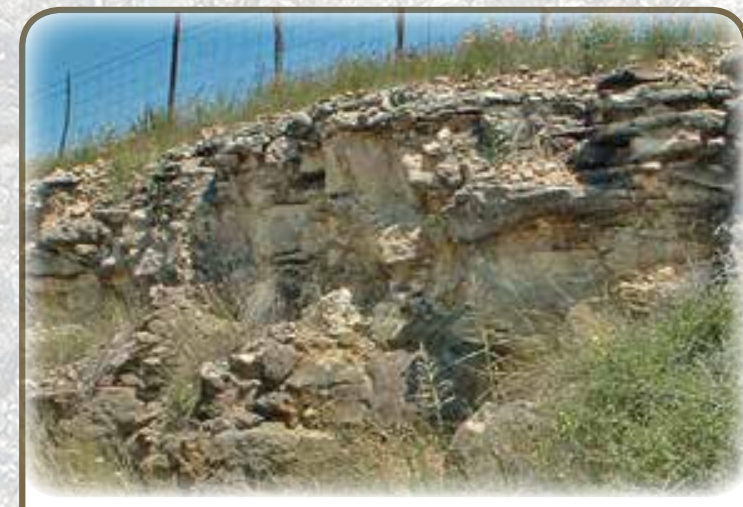

Exposed Austin Group in road cut excavation located on south side of U.S. Highway 90 and approximately midway between Sabinal and Knippa, eastern Uvalde County, Texas. Photograph taken May 29, 2012.

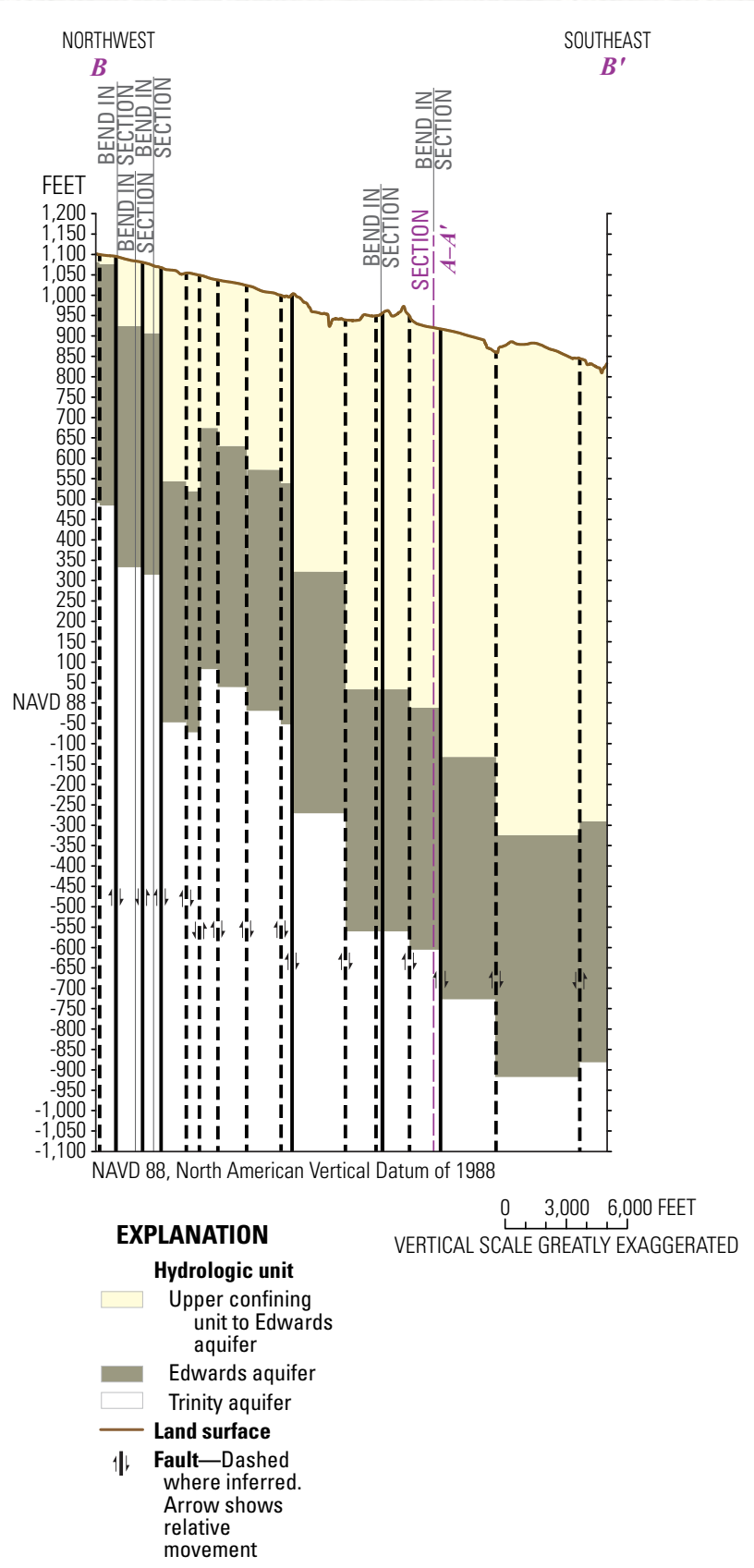

Figure 5. Hydrologic section $B-B^{\prime}$ showing vertical or nearly vertical, en echelon normal faults that are downthrown to the southeast. Location of trace $B-B$ 'shown on figure 3 .

in extensional fault systems to allow for deformation changes along the fault block (fig. 6). Relay ramps connect the foot wall of a fault segment to the hanging wall of the overhanging fault (Clark and Journey, 2006). Groundwater flow paths in the Edwards aquifer are influenced by this complex faulting in that some faults may function as barriers to groundwater flow where the total thickness of the aquifer is offset by at least 50 percent. In these locations, groundwater flow moves parallel to the strike of the fault. The amount of displacement along a particular fault tends to vary; thus, the effectiveness of a fault as a barrier to flow probably changes along the fault plane. 




Figure 6. Idealized view of the relay-ramp structure that dips to the northeast from the Uvalde Salient in Uvalde County, the relay-ramp structure that dips to the southwest from Medina County, and the inferred direction of groundwater flow paths towards the Knippa Gap structural low (trough).

In western Medina County, faulting within the Balcones Fault Zone has produced a relay-ramp structure that dips to the southwest from the Edwards aquifer recharge zone and extends westward (figs. 3,6). The faults in this area function as barriers to flow, and groundwater originating in northern Medina County moves down the relay ramp from as many as four separate, fault-bounded flow paths (Clark and Journey, 2006) downgradient (downdip) to the southwest towards the structural low (trough) in the Knippa Gap area (figs. 4, 6).

In Uvalde County, the rocks that make up the Edwards aquifer dip down from a structural high known as the Uvalde Salient towards the structural low (trough) (figs. 4, 6). Groundwater moving downgradient from near the end of a fault in the Uvalde Salient from the western part of the Edwards aquifer in the Maverick Basin is funneled down a relay ramp by faults that function as barriers to flow east-northeast towards the structural low (trough) in the Knippa Gap area where it joins groundwater flowing in from Medina County (figs. 4, 6). The combined flow from these two flow paths then flows through an area with minimal fault displacement in the Knippa Gap.

\section{This fact sheet is based on the following report:}

Clark, A.K., Pedraza, D.E., and Morris, R.R., 2013, Geologic framework, structure, and hydrogeologic characteristics of the Knippa Gap area in eastern Uvalde and western Medina Counties, Texas: U.S. Geological Survey Scientific Investigations Report 2013-5149, 35 p., 1 pl., http://pubs. usgs.gov/sir/2013/5149/.

\section{References Cited}

Clark, A.K., and Journey, C.A., 2006, Flow paths in the Edwards aquifer, northern Medina and northeastern Uvalde Counties, Texas, based on hydrologic identification and geochemical characterization and simulation: U.S. Geological Survey Scientific Investigations Report 2006-5200, 48 p.

George, P.G., Mace, R.E., and Petrossian, Rima, 2011, Aquifers of Texas: Texas Water Development Board Report 380, $172 \mathrm{p}$.

Maclay, R.W., and Land, L.F., 1988, Simulation of flow in the Edwards aquifer, San Antonio region, Texas, and refinement of storage and flow concepts: U.S. Geological Survey WaterSupply Paper 2336-A, 48 p.

\section{-By Rebecca B. Lambert, Allan K. Clark, Diana E. Pedraza, and Robert R. Morris}

\section{For additional information, contact}

Director, USGS Texas Water Science Center

http://tx.usgs.gov/

gs-w-txpublic-info@usgs.gov 